\title{
Obamas missilskjold og Rusland
}

\section{Henrik $\emptyset$. Breitenbauch}

\section{Det var ny teknologi og en ændret efterretnings- vurdering af Iran, der gav Obama mulighed for at droppe det planlagte missilskjold - og komme Rusland i møde}

USA ønsker ikke længere at oprette to omstridte anlæg i Polen og Tjekkiet til brug for missilforsvaret. Det annoncerede den amerikanske præsident Barack Obama i en opsigtsvækkende tale den 17 . september 2009. De to østeuropæiske installationer havde længe været en torn i øjet på Rusland på trods af, at de officielt kun skulle skabe beskyttelse mod den mulige trussel fra Iran.

Overordnet blev beslutningen da også begrundet med både den tekniske udvikling inden for missilforsvarsprojektet og med efterretningsmæssige vurderinger vedrørende Iran. Men beslutningen er reelt et led i USA's forvaltning af forholdet til Rusland. Udmeldingen var koordineret med en anden opsigtsvækkende tale, som netop omhandlede en ny start på forholdet til Rusland, og som blev holdt dagen efter af
NATOs ny generalsekretær, Anders Fogh Rasmussen. De to taler viser tilsammen, at den amerikanske regering ønsker at fastholde NATO som et centralt forum for forholdet til Rusland, og dermed i den sidste ende styrke multilaterale snarere end bilaterale forbindelser, ikke mindst til Rusland.

Analysen her tager derfor udgangspunkt i Obamas beslutning, gør status over missilforsvarsprogrammet i lyset af talen, og ser derefter endelig på NATO-forslaget om et nyt pragmatisk samarbejde med Rusland. Alt sammen med henblik på at kunne give en vurdering af, hvilke faktorer, der kan siges at have spillet ind i forhold til den amerikanske beslutning - og dermed noget om, hvad det er for en overordnet udenrigspolitisk stil Obama lægger for dagen. 


\section{'Faseinddelt og tilpasningsegnet'}

Aflysningen af missilforsvarsanlæggene i Østeuropa er en af den slags historier, som væver en hel række af niveauer i international politik sammen. Den kan ikke fortælles ud fra sine tekniske eller trusselsmæssige meritter alene, altså de, der har at gøre med rationalet bag udviklingen af det nuværende amerikanske missilskjold.

Overordnet var ønsket om et bedre forhold til Rusland afgørende for beslutningen, selvom det var tekniske udviklinger inden for missilforsvarsprogrammet, der muliggjorde den, og selvom Iran også er en del af den offentlige og reelle begrundelse for omlægningen.

Obamas udmelding omkring ændringen af missilforsvaret i Europa er hovedsagelig en plan for, hvordan det vil komme til at se ud i fremtiden. Planen er 'faseinddelt og tilpasningsegnet'. Den bygger dels på en efterretningsvurdering af den iranske missiltrussel, dels på et ønske om at anvende teknologi, der beviseligt fungerer, er omkostningseffektiv, og endelig tilpasningsegnet til et omskifteligt sikkerhedsmiljø. Planen indeholder fire faser, som hver især består af et omtrentligt årstal og en tilhørende række systemer, fra sensorer til deciderede våbensystemer.

Efterretningsvurderingen gennemgås naturligvis ikke i detaljer. Pointen er, at truslen fra iranske missiler med kort- og mellemlang rækkevidde vokser hurtigere end tidligere forudsagt, mens truslen forbundet med iranske interkontinentale missiler (ICBM) vokser langsommere end tidligere vurderet. Truslen mod allierede og de amerikanske styrker, der er udstationeret på allieret jord i Europa, vokser altså mere end den gør mod det amerikanske territorium.

De fire faser eller årstal er omkring 2011, 2015, 2018 og 2020. Fælles for de fire faser er, at de bygger på en imødeset teknologisk udvikling af Standard Missile-3 (SM-3) . Denne missiltype er nu primært anvendt på den amerikanske flådes Aegis-krydsere. Aegis er således et af de mest markante 'små' missilforsvarssystemer, som skal beskytte missionsområder: det vil sige systemer med en geografisk udstrækning på op til et par hundrede kilometer i diameter, og som hovedsageligt er rettet mod missiler med kort- til mellemlang rækkevidde.

Den forventede udvikling af SM-3 betyder imidlertid, at rækkevidden af disse og dermed af Aegis-skjoldet forventes at blive udvidet betragteligt over de næste 10 år således, at det meste af det europæiske kontinent, herunder NATO-landene, vil kunne dækkes fra Aegis-krydsere eller fra jordbaserede installationer. Obamas udmelding indebærer nemlig ikke en ren skibsbåret model, men snarere, at SM-3 udvikles så meget, at det giver mening at installere også disse missiler på landan- 
læg. Samtidig udvides deres evne til at imødegå trusler så meget, at 2018fasen sigter mod også at kunne imødegå langtrækkende missiler under ICBM-grænsen, mens 2020-fasen tillige sigter mod den 'potentielle fremtidige ICBM-trussel mod USA'.

Skiftet til SM-3 betyder, at der ifølge beslutningen ikke længere er behov for det polske anlæg, som skulle have bestået af 10 - væsentligt større - GBI eller Ground-Based Interceptor-missiler.

Fordi også sensorsystemerne - forskellige former for radarer - både udvikles undervejs og integreres i et samlet varslingssystem, så vil der heller ikke være behov for den store radarinstallation i Tjekkiet.

Samlet er der fem fordele ved dette skift, fastslår det Hvide Hus. Man fastholder evnen til at forsvare amerikansk territorium mod langdistance missiltrusler, fordi fase fire i 2020 vil introducere en generation af SM3, som kan knyttes til det eksisterende system, baseret på GBI i Californien og Alaska. Man sikrer en hurtigere beskyttelse af udsendt amerikanske personel og af allieret territorium og befolkninger (det planlagte polske anlæg ville ikke have dækket det sydøstlige Europa). Og endelig anvender man teknologi, der beviseligt virker, og som sikrer fleksible muligheder for at opgradere og videreudvikle systemerne.

Men hvordan flugter Obamas udmelding med den overordnede udvikling i den amerikanske missilfor- svarspolitik? Her er vi nødt til at blive lidt tekniske og gå noget tilbage $\mathrm{i}$ tiden for at opdage de store linjer, der har ledt frem til det nuværende Ballistic Missile Defense System (BMDS).

\section{Fra stjernekrig til alliancegods}

Missilforsvar er en underlig blanding af teknologi og symbolik. For eksempel fungerer et missilforsvar efter hensigten, hvis de lande, det er rettet imod, tror på, at det fungerer. Det behøver ikke nødvendigvis fungere teknisk. Derfor er den politiske og officielle måde, der tales om missilforsvar på, af stor vigtighed, fordi den er med til skabe troværdighed.

Den amerikanske stat er heller ikke karrig med oplysninger om missilforsvarets karakter og udvikling. Missile Defense Agency (MDA) er den organisation inden for det amerikanske forsvar, der har ansvar for missilforsvaret. Den har en omfattende og ajourført hjemmeside med officielle beskrivelser af det samlede projekt, status for integration af sensorer, aktive delelementer og så videre. Indholdet på hjemmesiden er naturligvis særligt udvalgt og skal læses i lyset af den symbolske karakter, missilforsvarsprojektet har.

Missilforsvar har en lang forhistorie. Så langt tilbage, der har været missiler af moderne type, har der været militære, civile og industrielle forsvarstanker om at udvikle systemer til forsvar mod sådanne typer angreb. Disse anti-ballistiske visioner 
og projekter fik i 1960'erne stormagterne til at frygte, at en faktisk udvikling og implementering ville rokke ved den 'gensidigt sikrede ødelæggelse' (MAD), der i form af afskrækkelse understøttede den strategiske bipolare stabilitet.

Man frygtede med andre ord, at hvis én stormagt fik et effektivt missilforsvar, så ville samme stormagt uden repressalier kunne angribe den anden stormagt. Derfor ville stormagt nummer to have et stort incitament til at angribe den første stormagt, inden denne færdigudviklede et sådant system. Frygten for et sammenbrud af afskrækkelsens paradoksale stabilitet fik i 1972 stormagterne til at indgå en traktat om begrænsning af anti-ballistiske-missilsystemer (ABM-traktaten). Med denne traktat var missilforsvaret $\mathrm{i}$ princippet sat i bero.

Anden fase fulgte med den amerikanske præsident Reagans Strategic Defense Initiative (SDI), som blev lanceret i marts 1983. SDI blev også kendt som stjernekrigsprojektet, fordi det indeholdt idéen om rumbaserede forsvarssystemer imod angreb fra ballistiske missiler.

SDI blev dengang kritiseret for at risikere at undergrave ABM-traktaten, men blev også rost, fordi investeringen i projektet var så massiv, at den fik Sovjetunionens ledere til at miste troen på deres eget lands evne til at imødegå de amerikanske udgifter til teknologiudvikling. Der er en pæn grad af kontinuitet mellem SDI og det nuværende BMDS både i form af de enkelte aktive modforanstaltninger og sensorsystemer, og hvad angår den generelle tanke omkring et integreret missilforsvar. Et missilforsvar er integreret, når det har en teoretisk mulighed for at gribe ind i alle faser af den bane, som det missil, man ønsker at beskytte sig imod, tager - fra affyring til lige før det rammer.

Clinton-regeringen byggede i 1990'erne videre på det såkaldte stjernekrigsprojekt fra 1980'erne. I 1996 blev det besluttet at opgradere projektet omkring et nationalt missilforsvar fra udviklingsstatus til et indkøbsprogram, et sidste skridt før en egentlig ibrugtagning. Det nationale missilforsvar (NMD) var således tænkt som et system, der skulle kunne beskytte det kontinentale USA mod langtrækkende missilangreb fra mindre lande, og således ikke bryde med ABM-traktaten. Clinton udskød i 2000 beslutningen om en egentlig ibrugtagning til den næste præsident.

Bush-regeringen valgte ikke kun at gå videre med en egentlig ibrugtagning af NMD, men omdøbte også i 2001 programmet til det mere neutrale Ballistic Missile Defense System. Denne afnationalisering af navnet byggede på et teknologisk og et politisk argument. Det tekniske element bestod i, at muligheden for at integrere forskellige sensor- og varslingssystemer også gjorde det oplagt at integrere de aktive antiballistiske sy- 
stemer, altså våben-delene. Parallelt med NMD, der jo skulle beskytte det amerikanske kontinent mod interkontinentale missiler, har det amerikanske forsvar også udviklet forskellige missionsområde-dækkende missilforsvarssystemer - hovedsageligt rettet mod kort- og mellemdistancemissiler. Det mest kendte af disse er Patriot-systemet. Et andet er Aegissystemet, som altså kommer til at udgøre rygraden i det amerikanske missilforsvar i Europa.

NATO fik begyndende ejerskab med det politiske argument. Det handlede om, at det integrerede missilforsvar, inklusive de mindre missionsområde- og skibsbårne systemer, i princippet ville kunne dække langt mere end det amerikanske kontinent, herunder både udstationerede amerikanske styrker og allierede landes territorier. Herunder introducerede Bush-regeringen planen om, at kernedelen af missilforsvaret, det tidligere NMD, skulle udvides med de omtalte installationer $i$ Tjekkiet og i Polen. Bush-regeringen forklarede konsekvent denne udvidelse med hensynet til en beskyttelse mod en mulig trussel fra Iran, og understregede at de to østeuropæiske dele ikke ville rokke ved MAD mellem USA og Rusland.

Men samtidig fratrådte USA i 2002 ABM-traktaten, og understregede dermed på den ene side den manglende tro i den daværende amerikanske regering på multilaterale løsninger, og på den anden side, at man så et reelt behov på længere sigt for systemer, som gik ud over, hvad ABM-traktaten ville tillade - selvom man gjorde sig store anstrengelser for at overbevise Rusland (og Kina) om, at der stadig ville være MAD mellem disse lande og USA.

For Putins Rusland har de østeuropæiske anlæg handlet om en styrkeprøve og været et led i en udvidelse af den amerikanske interessesfære. Sådan har Rusland opfattet udvidelserne af EU og NATO, og placeringen af amerikanske forsvarsinstallationer på tidligere sovjetisk domæne blev opfattet som en direkte provokation.

\section{Obamas politiske manøvrerum}

Når SM-3-missilerne begynder at kunne dække et geografisk område af samme størrelse som GBI i Europa, så svækkes argumentet for de østeuropæiske installationer tilsvarende. Den teknologiske udvikling giver altså et politisk manøvrerum. Dette gælder i hvert fald for så vidt som man taler om beskyttelse af europæisk territorium og ikke ser på, hvilken effekt SM-3 vil kunne have i forhold til beskyttelsen af det amerikanske territorium, altså dét, som det gamle NMD skulle dække. I forhold til Iran vil der, særligt med den fremhævede efterretningsvurdering, altså ikke ske en svækkelse af det samlede forsvar af NATOs område.

Men selv når SM-3-missilerne når 
deres fulde udvikling, vil de ikke enkeltvist kunne udfylde samme funktion som GBI-missilerne med deres længere rækkevidde og større lasteevne. Det er altså efterretningsvurderingens påpegning af, at den største trussel (eller trussel om trussel) fra iransk side er fra kort- og mellemdistance missiler snarere end ICBM, som gør det muligt at skifte vægten fra GBI til SM-3-missiler.

Omvendt ville den påtænkte GBIinstallation i Polen altid skulle begrænse antallet af GBI-missiler for ikke at ødelægge MAD med Rusland. Og i tilfælde af et egentligt angreb stiller et begrænset antal missiler meget store krav til, at hvert missil fungerer efter hensigten. For så vidt som missilforsvarssystemerne overhovedet vil kunne fungere nogenlunde i virkeligheden, er det derfor et stærkt argument for at have mange anti-ballistiske missiler. Det argument taler for en SM-3-løsning, fordi hver af de mange flere SM-3-bærende platforme og installationer kan indeholde op til over ti gange så mange SM-3 missiler.

Hertil kommer, at missilforsvaret som netværk betragtet bliver uendeligt meget stærkere ved at bestå af et meget stort antal noder - installationer og platforme - snarere end kun installationen i Polen plus Alaska og Vandenberg (hertil kommer integrationen på sensorsiden).

Der er altså vundet politisk manøvrerum i forhold til det europæiske kontinent. Obamas udmelding er da også floromvunden, hvad angår effekten af beskyttelsen af det amerikanske kontinent - i talen refererer han til at 'vedligeholde og udbygge' dette, mens det tilhørende faktablad lidt snirklet peger på, at tilgangen 'udvikler evnen til at udvide vores nuværende beskyttelse' af det amerikanske territorium. Men hvis teknologien i samspil med missilforsvarets symbolske natur har givet Obama et politisk råderum, hvad anvender han det så til? Hvilke logikker ligger bag de officielle ord?

\section{NATO inviterer med Obamas støtte}

Det amerikanske forhold til Rusland spiller en meget stor rolle. Herunder er det vigtigt, at Obama gerne ser, at NATO får en central rolle som et multilateralt forum for diskussion med Rusland. Obama ønsker med andre ord ikke at fortsætte præsident Bushs personliggjorte forhold til den russiske præsident, og hans regering ønsker også - i hvert fald i udgangspunktet- at styrke multilaterale frem for bilaterale forbindelser i relationen til Rusland.

Derfor står Obamas udmelding og tale ikke alene - den havde en tydelig partner i den første store tale, som NATOs ny generalsekretær, Anders Fogh Rasmussen, holdt den 18. september 2009 - dagen efter Obamas udmelding. Talen inviterede Rusland til en ny start på forholdet til NATO. Den må uden tvivl ses som et resultat ikke kun af koordi- 
nation mellem det Hvide Hus og NATOs hovedkvarter, men også som et direkte led i den nye amerikanske politik over for Rusland. NATOs Ruslandspolitik er (også) et udtryk for, at den nuværende amerikanske regering hælder mere til multilaterale løsninger, end forgængeren.

Fogh foreslår i sin tale at 'kickstarte' forholdet til Rusland efter krisen, der opstod med Georgien-krigen og dens efterspil fra august $2008 \mathrm{og}$ frem. Talens logik - og russernes umiddelbare respons - viser de problemer, der er for NATOs forsøg på at gøre Rusland til en forudsigelig samarbejdspartner. Og dermed for USA i at gøre sit forhold til Rusland til en multilateral snarere end bilateral affære.

Grundlæggende ønsker NATO både konkret, nyttigt samarbejde mellem Alliancen og Rusland, og at overbevise Rusland om, at det skal opfatte sikkerhed på samme brede måde, som NATO gør - så det ikke handler om nulsumsspil og overlevelse, men også om klimaforandringer og godt naboskab. Men det kan Rusland ikke gøre, hvis Rusland skal være en stormagt - og derfor vil russerne altid foretrække direkte kontakt med amerikanerne frem for at gå via den multilaterale kanal, som NATO udgør. Derfor var det også paradoksalt, at Generalsekretærens tale lagde så stor vægt på, at forholdet skulle bygge på realisme.

Talen nævner ikke mindre end 13 gange, at det nye forhold skal bygge på realisme - en praktisk og virkelighedsnær relation, hvor man kan se hinanden i øjnene og ikke lader som om, billedet viser noget andet, end det gør. Det er korrekt, at forholdet mellem Rusland og NATO og resten af vesten i forskellige konstellationer har været præget af manglende realisme i store dele af perioden siden slutningen af den kolde krig.

Fra vestens side undervurderede man gang på gang, hvor langt Rusland er fra at være vestlig, og hvor fernistynde moderniseringsprocesser, der kun har varet 10-20 år, kan være. Omvendt har Rusland aldrig helt vænnet sig til ikke at være Sovjetunionen - en skræmmende kolos, som hellere vil frygtes end elskes.

Talen foreslår tre indsatsområder. For det første: praktisk samarbejde baseret på fælles interesser mellem NATO og Rusland (i modsætning til NATO, der også er et værdifællesskab). Samarbejdet kan dreje sig om terror, ikke-spredning af masseødelæggelsesvåben og missiler samt om våbenkontrolaftaler, missilforsvar, Afghanistan og endelig maritim sikkerhed i form af pirateribekæmpelse. For det andet opfordrede Fogh til at forny samarbejdet i det formelle forum for dialog, NATO-Russia Council (NRC). For det tredje foreslog han, at de to parter sammen skulle udarbejde en fælles analyse af trusler og udfordringer. Praktisk samarbejde skal man ikke afskrive den konkrete nytte af. Og det giver 
sig selv, at NRC skal anvendes, hvis man skal genstarte relationen.

Men forslaget om den fælles strategiske analyse viser, hvordan NATO og Rusland har nogle helt forskellige antagelser om den internationale politiks karakter. Set inde fra NATO og Alliancens nordvestlige kerne fra USA over Storbritannien til Holland og Danmark - så er forslaget helt på linje med, hvordan man laver sikkerhedspolitik, nemlig gennem flere og mere eksplicitte strategiprocesser. Strategi skal være en konstant proces, som skaber en lærende organisation. Og sikkerhedspolitisk strategi handler lige så meget om uhåndterlige risici - fra klimaforandringer til demografi som det handler om militære trusler. På den måde går det hånd i hånd med processen hen imod et nyt strategisk koncept som en alliance-terapeutisk samtale. Det er et fint udtryk for, hvordan toppen af NATO tænker sikkerhedspolitik som proces - og at man ønsker, at de nye medlemslande udvikler en forståelse af både brede sikkerhedspolitiske og snævert militære udfordringer.

Tanken om en fælles strategisk analyse flugter også med den interne situation i NATO. Under Fogh skal medlemslandene blive enige om et nyt strategisk koncept, som beskriver, hvorfor NATO findes, og hvordan og hvor NATO skal handle. Herunder skal man berolige de nyeste medlemslande, som er bekymrede for, om Rusland kan blive en trus- sel, og for om NATOs sikkerhedsgaranti vil fungere i praksis. Hvis forholdet til Rusland forbedres, så forsvinder nogle af grundene til disse bekymringer. Endelig viser netop forholdet til Rusland, hvorfor NATO blev skabt, og på sin vis også hvad NATO skal lave fremover, selvom det er rarere at tale om risici fra naturen end om trusler fra militære fjender.

\section{NATO kan ikke erstatte USA}

NATOs ideer om praktisk samarbejde baseret på fælles interesser bygger på en forventning om, at der kommer gensidig tillid ud af samarbejdet. Men der er intet, der tyder på, at man kan vikle Rusland ind i rundkredspædagogik og så forvente, at der kommer noget godt ud af det. Faktisk er der grund til at frygte, at russerne bare irriteres over en sådan øvelse, og fornemmer, at der her tales ned til deres mere håndfaste forståelse af den internationale politik. Ruslands ligefremme NATO-ambassadør, Dmitrij Rogozin, afviste allerede samme dag som Foghs tale, at NATOs brede sikkerhedsbegreb har bragt noget godt med sig:

"NATO har i de sidste to årtier lidt af en identitetskrise. Denne krise er ikke blevet løst hverken ved østudvidelserne eller de desperate forsøg på at inkludere ethvert tænkeligt emne på sin dagsorden: terrorisme-bekæmpelsen, energisikkerhed, cyber-sikkerhed, pirateri og kli- 
maforandringer."

Rogozins kritik viser tydeligt, at russerne grundlæggende ikke tænker i de samme (brede) sikkerhedspolitiske baner som NATO med fokus på trusler, der kommer lige så meget fra svagheder som fra styrker, såsom ustabilitet, svage stater, klimaforandringer, etc.

Rusland tænker i stedet grundlæggende på sikkerhed som et militært anliggende, og som et anliggende, der er relateret til magtkapabiliteter, ikke til værdifællesskaber - altså mere på våben end på holdninger.

Rogozin henviser eksplicit til den reelle magtpolitik, russerne ser bag det venlige tilbud om dialog. For at imødekomme russerne vil NATO blive nødt til at "forandre det, der forekommer at være NATOs tankesæt - at der kun skal være ét magtcentrum." Implicit henviser han dermed til en opdeling af Europa i forskellige geopolitiske interessesfærer.

Det er NATOs paradoksale skæbne i forhold til Rusland: Anders Fogh Rasmussen har som generalsekretær ret i, at NATOs (og EUs) styrker ligger i deres socialiserende effekt. Små og mellemstore lande vil gerne vikles ind i gensidigt forpligtende samarbejde, som alle vinder ved. Men NATO bliver næppe taget alvorligt af russerne, før russerne synes, de har fået den status, de fortjener. Og det er kun USA, der kan give dem dét. NATO kan derfor kun tilbyde for lidt (hvis Rusland, som $\mathrm{nu}$, ser sig ignoreret af USA) eller være irrelevant (hvis USA giver Rusland den opmærksomhed, russerne synes, de fortjener). Sådan vil det være, indtil man kan overbevise Rusland om, at sikkerhedspolitik og sikkerhedssamarbejde også handler om at håndtere bredere udfordringer, som endnu ikke er blevet til militære trusler - og at NATO dermed er på et niveau, der er relevant for Rusland.

NATO og Fogh får dermed svært ved at udgøre det naturlige forum for det amerikansk-russiske forhold.

Spørgsmålet er så, hvor meget Obama får ud af sin beslutning om missilforsvaret i Europa, hvad angår Rusland, Østeuropa, Iran og udenrigspolitikken som sådan?

\section{Tilpasningsegnet storpolitik?}

Den primære effekt af Obamas udmelding har dermed været at omgøre en - mest symbolsk begrundet - beslutning fra hans forgænger, George W. Bush. Forholdet til Rusland kommer til at afhænge af mange andre faktorer end missilforsvaret, selvom det er klart, at en knast er blevet fjernet. Grundlæggende er der ingen grund til at tro, at Ruslands selvforståelse vil blive forandret af hverken NATOs udspil eller andre, USA vil komme med. Derfor giver det selvfølgelig netop mening at bygge sådanne forslag på realisme og pragmatisk samarbejde. Men forholdet til Rusland kan ikke kun bygge på fleksibilitet - tilpasningsegnet- 
hed - det må også sætte klare grænser for hvad vesten, NATO og USA vil acceptere.

Beslutningen om at skrotte de to anlæg i Østeuropa har stor betydning for Polen og Tjekkiet. Disse landes regeringer havde under folkelig modstand netop færdigforhandlet aftaler om placering af de to amerikanske installationer. Kursændringen har derfor vakt vrede i politiske kredse, ikke mindst fordi beslutningen blev opfattet som en symbolsk nedgradering af den amerikanske sikkerhedsgaranti. Sådan er det også blevet opfattet $\mathrm{i}$ andre østeuropæiske lande, og herunder ikke mindst de nyere medlemslande af NATO samt de lande, der gør sig forhåbninger om NATO-medlemskab længere nede ad vejen i kraft af deres tilknytning til NATO gennem PfP-fællesskabet og medlemskabsplanen (MAP).

Den omtalte proces mod et nyt strategisk koncept har netop til formål at sikre enighed om alliancens betydning og den amerikanske sikkerhedsgaranti over for de mest nervøse medlemslande i øst. Beslutningen i september er da også endt med en kompensation til Polen, så USA nu i stedet opstiller et batteri Patriot-missiler i stedet for den planlagte installation.

Hvad angår situationen med Iran, så er landets regime ikke er blevet væsentligt mindre konfrontatorisk over for vesten siden Shahens fald.
Præstestyrets udvikling af diverse våbensystemer udgør en reel grund til bekymring, og denne bekymring må naturligt stige, efterhånden som våbensystemerne bliver klare til anvendelse. Den ovenstående analyse af præsident Obamas valg skal altså også ses i dette lys; lige så meget et udslag af nødvendighed som et valg. På den måde er det netop den stigende bekymring for reelle trusler fra Iran, blandt andet i form af kortog mellemdistance-missiler, som har fjernet det symbolske grundlag for den tidligere amerikanske regerings valg om at opstille de to anlæg i Østeuropa.

Obama-regeringens ønske om at distancere sig symbolsk og reelt fra Bush-regeringens overordnede linje i udenrigspolitikken skinner igennem i beslutningen om missilforsvaret i Europa. Hvor forgængerens stil var højttravende visionær og ofte lod retorisk form og politisk indhold flugte hinanden og foretrak bilaterale og uformelle relationer, så ønsker Obama at være pragmatisk, undlade signalpolitik - altså lade politiske valg være andet end det, de umiddelbart indeholder - og arbejde gennem etablerede institutioner. Men som vi har set, er det ikke sikkert, at storpolitikkens betingelser tilpasser sig Obamas kursændring.

Henrik $\emptyset$. Breitenbauch er ph.d., og seniorforsker ved Dansk Institut for Militere Studier. 